\title{
Análise do gerenciamento dos resíduos sólidos dos serviços de saúde em Curitiba, com ênfase no tratamento e destino final, e implicações socioambientais
}

\author{
Maria Inez Antonia Pelacani SPINA
}

Dissertação de Mestrado: Curso de Mestrado em Geografia - UFPR

Data da defesa: 26 set. 2003

Banca:

Sony Cortese Caneparo (orientadora)

Everton Passos

Tela Elisa Carraro

\section{RESUMO}

Esta pesquisa tem por objetivo conhecer e analisar o gerenciamento dos Resíduos Sólidos dos Serviços de Saúde (RSSS) desenvolvido pelo poder público e empresas de saúde de Curitiba durante o período compreendido entre os anos de 1989 e 2001, evidenciando os problemas socioambientais que as etapas referentes ao manejo, tratamento e destino final dos resíduos infectantes podem causar ao ambiente e à saúde pública. Destaca que esses resíduos originam-se nas dependências internas das empresas prestadoras de serviços de saúde e que, de acordo com as características que apresentam, podem receber destinos finais diferenciados quando são gerenciados convenientemente, em conformidade com os parâmetros do Desenvolvimento Sustentável. Em Curitiba, o poder público, desde 1989, para gerenciar de forma integrada os resíduos sólidos, desenvolveu o programa de coleta seletiva denominado "Lixo que não é lixo hospitalar", viabilizando o destino correto aos resíduos comuns, recicláveis e infectantes gerados pelas empresas de saúde, contribuindo para a preservação do meio ambiente e manutenção da qualidade de vida de sua população. Entendendo que os RSSS são um produto eminentemente urbano, o respaldo metodológico foi obtido pelo Siste- ma Meio Ambiente Urbano, considerando-se as questões físico-ambientais e político-sociais nele implícitas. Curitiba possui 816 empresas de saúde que se encontram cadastradas ao programa de coleta seletiva. As segregações prévias ocorrem no interior dessas unidades, concedendo destino final diferenciado a cada categoria de resíduos. Verificou-se que o gerenciamento integrado dos RSSS realizado em Curitiba vem ocorrendo de modo a atender à preservação ambiental, possibilitando a redução da quantidade de resíduos infectantes destinados às valas sépticas. Observou-se também que há necessidade de ampliação dos serviços de coleta diferenciada em todas as empresas de saúde geradoras de resíduos infectantes existentes no município, mediante cadastramento ao programa. Ressalta-se que o monitoramento periódico das condições físico-ambientais da área das valas sépticas é fundamental para que se possam dimensionar as condições dos componentes físicos dessa área e evitar os efeitos nocivos ao ambiente e à qualidade de vida da população decorrentes da decomposição desses resíduos.

\section{Palavras-chave:}

Resíduos sólidos dos serviços de saúde, gerenciamento. 